\title{
Proceeding
}

Supplementary Issue: Winter Conferences of Sports Science. Costa Blanca Sports Science Events, 22-23 March 2021. Alicante, Spain.

\section{The effect of selective exercises on developing motor abilities, basic skills, and mental perception among football players}

\author{
NAWAR ABDULLAH HUSSEIN ALLAMI ${ }^{1}$, GHAITH ABDULLAH HUSSEIN, KHALID KADHIM RESAN
} $\mathrm{AL}-\mathrm{LAM}{ }^{3}$

${ }^{1}$ College of Administration and Economics, Al-Qadisiyah University, Iraq

${ }^{2}$ College of Pharmacy, Al-Qadisiyah University, Iraq

${ }^{3}$ Babil Governorate Education Directorate, Iraq

\begin{abstract}
The early stages of sports training are very important because they build the basis for future training stages. Skills are considered one of the most important training objectives for early training in life as it works to acquire basic skills and raise their performance to an advanced stage of mastery, and that the goal of training also requires a high level of motor abilities that require reaching high stages of maturity and development from this important age stage. The researchers believe that because is a trainer, there is a lack of interest in the process of training motor abilities, mental abilities. The trainers use a few training methods fit to developing the performance of these skills among the young players. Therefore, the researchers decided to use special exercises to develop the movement abilities, basic skills, and mental perception of the research sample for it to be effective training methods used by active trainers. Identify the effect of selective exercises on their development of motor abilities, basic skills, and mental perception. Special exercises have a clear effect on the experimental group in developing motor abilities and mental perception.

Keywords: Skills; Motor abilities; Mental perception; Football.

Cite this article as:

Allami, N.A.H., Hussein, G.A., \& Al-Lami, K.K.R. (2021). The effect of selective exercises on developing motor abilities, basic skills, and mental perception among football players. Journal of Human Sport and Exercise, 16(3proc), S1425-S1433. https://doi.org/10.14198/ihse.2021.16.Proc3.58

Corresponding author. College of Administration and Economics, Al-Qadisiyah University, Iraq.

E-mail: nawar.bdullah@qu.edu.iq

Abstract submitted to: Winter Conferences of Sports Science. Costa Blanca Sports Science Events, 22-23 March 2021. Alicante, Spain.

JOURNAL OF HUMAN SPORT \& EXERCISE ISSN 1988-5202.

(c) Faculty of Education. University of Alicante.

doi:10.14198/jhse.2021.16.Proc3.58
\end{abstract}




\section{INTRODUCTION}

Sports training in football aims to develop all components that serve the activity required to be performed. it seeks to achieve the best possible level, through the use of exercises to develop the players' abilities and their physical, skill, mental, and planning capabilities, thus allowing them to complete their duties at the highest level of competence and to reaching to the supreme levels and get the most benefit for them and their team. It is no secret that football is one of the games that has received great attention in many countries because of its great popularity. Therefore, we see specialists seeking to develop this game by developing the players' levels of skill, physical, tactical, mental, and psychological.

The motor abilities and skills have great importance, so, clear focus on it because modern playing has become more complex compared to playing styles in past years. And the special exercises are an important training method that works to raise the athletic level of players because they develop the physical characteristics that work on the process of integrating performance and raising the level of the players' planning understanding. The importance of the research is preparing special selective exercises to develop the mobility abilities, basic skills, and mental perception of young football players, to be an important means on which trainers depend in order to achieve results that raise the level of ambition and reach higher levels.

\section{Research problems}

The first training stages are very important because they form the basis for the subsequent training stages in sports training. The skill preparation is considered one of the most important training goals for the early stages, as the acquisition of basic skills and upgrading its performance to advanced levels for Mastering of the training goal as this requires a high level of potential and movement abilities that require advanced stages of maturity and development for this early age.

The researchers believe that there is a lack of interest in the process of training motor abilities as well as mental abilities. The trainers use few training means fit with their importance in developing the performance of these skills among the young players. Therefore, the researchers decided to use special selective exercises in order to develop the motor abilities, the basic skills and the mental perception of the research sample due to the training means are effective by the active trainers.

\section{Research Objectives}

1. The use of special selective exercises to develop some motor abilities, basic skills, and mental perception of the research sample.

2. Identify the effect of special selective exercises in developing some motor abilities, basic skills, and mental perception of the research sample.

\section{Research hypotheses}

1. Special selective exercises have a positive effect on developing some motor abilities, basic skills, and mental perception of the research sample.

\section{Research fields}

1- The Human Field: The young players of the Daghara Football Club.

2- Time Field: Research period from 12/1/2019 to $1 / 7 / 2019$

3- The duration of the exams and the curriculum is from 1/2/2019 to 6/5/2019.

4- place Field: stadium of the Dagara Football Club. 


\section{METHODOLOGY}

The researchers have used the experimental method for its relevance to the research problem.

\section{The research community and its sample}

The research community consists of players from the governorate's football clubs for young, with five clubs (Al-Daghara, Al-Ettifaq, Al-Badir, Al-Mahanawiya, and Afak) and the league participants for the season (20182019). The researchers selected the sample (Intentional manner) of Daghara club players for the young category, ranging in age from (14-16) years, in order to meet all requirements for the success of the research and the players registered with the Iraqi Football unity for the season (2018-2019) at (27). The sample was randomly selected, amounting to (20) players after excluding (4) goalkeepers, (2) a player injured (1) player who did not comply with training. They were divided into two groups (control and experimental) and each group consists of (10) players by drawing lots randomly.

\section{Homogeneity and equivalence}

To ensure the homogeneity of the research sample and the researched variables that effect the results of the study, the researchers worked on two tables, the first for homogeneity and the second for equivalence, and we see that the research sample is naturally distributed and therefore homogeneous and equivalent.

Table 1. Demonstrates the homogeneity of the two research groups for variable height, weight, age, and training age.

\begin{tabular}{llcccccc}
\hline \multirow{2}{*}{$\mathrm{N}$} & \multirow{2}{*}{ The parameter } & \multicolumn{2}{c}{ Control group } & \multicolumn{2}{c}{ Experimental group } & \multirow{2}{*}{ T value } & \multirow{2}{*}{ Significant } \\
\cline { 3 - 6 } & & $\begin{array}{c}\text { Arithmetic } \\
\text { mean }\end{array}$ & $\begin{array}{c}\text { Standard } \\
\text { deviation }\end{array}$ & $\begin{array}{c}\text { Arithmetic } \\
\text { mean }\end{array}$ & $\begin{array}{c}\text { Standard } \\
\text { deviation }\end{array}$ & Calculator & \\
\hline 1 & The length $(\mathrm{CM})$ & 167.1 & 2.11 & 167.5 & 1.97 & 1.94 & Random \\
2 & The weight $(\mathrm{kg})$ & 55.7 & 1.67 & 56.1 & 2.04 & 1.02 & Random \\
3 & The age (year) & 15.2 & 1.37 & 15.3 & 0.99 & 1.37 & Random \\
4 & Training age-year & 2.1 & 0.54 & 2 & 1.84 & 1.24 & Random \\
\hline
\end{tabular}

Table 2. Showed the equivalence of the experimental and control group for the studied variables.

\begin{tabular}{|c|c|c|c|c|c|c|c|c|}
\hline \multirow[b]{2}{*}{$\mathrm{N}$} & \multirow[b]{2}{*}{ The parameters } & \multicolumn{2}{|c|}{ Experimental group } & \multicolumn{2}{|c|}{ Control group } & \multirow[b]{2}{*}{$\begin{array}{l}\text { T value } \\
\text { accounted }\end{array}$} & \multirow[b]{2}{*}{ T value } & \multirow[b]{2}{*}{$\begin{array}{l}\text { Significant } \\
\text { level }\end{array}$} \\
\hline & & $\begin{array}{c}\text { Arithmetic } \\
\text { mean }\end{array}$ & $\begin{array}{l}\text { Standard } \\
\text { deviation }\end{array}$ & $\begin{array}{c}\text { Arithmetic } \\
\text { mean }\end{array}$ & $\begin{array}{l}\text { Standard } \\
\text { deviation }\end{array}$ & & & \\
\hline 1 & The fitness & 10.21 & 1,25 & 10,18 & 1.39 & 1.88 & & Random \\
\hline 2 & Compatibility test & 9.55 & 1.84 & 10.01 & 1.12 & 0.92 & & Random \\
\hline 3 & Balance test & 5.98 & 0.87 & 5.79 & 0.57 & 1.54 & & Random \\
\hline 4 & Mental perception & 55.66 & 2.04 & 55.48 & 1.88 & 2.06 & 2.10 & Random \\
\hline 5 & Suppression test & 2.57 & 1.37 & 2.81 & 1.36 & 1.05 & & Random \\
\hline 6 & Handling test & 3.22 & 0.91 & 3.33 & 0.74 & 0.68 & & Random \\
\hline 7 & Rolling test & 3.11 & 1.25 & 3.09 & 088 & 1.68 & & Random \\
\hline
\end{tabular}

\section{Methods for gathering information}

Arab and foreign references, personal interviews, questionnaires, results recording form, observation, measurement and testing, assistance work team, exploratory experiment, electronic calculator, stopwatch, tape measure, medical scale, football field, football balls, whistles, various signs, and device Computer. 


\section{Research procedures}

Researchers depended on the football references in order to determine the most important motor abilities, basic skills, mental perception. Choosing the most important special tests to measure the study variables as they were determined through a questionnaire form, gives to specialized experts, and the important elements were chosen as shown in Table (2-3).

Table 3. Showed the studies' characters and their tests.

\begin{tabular}{lll}
\hline & Studied character & The test \\
\hline 1 & The fitness & Running test by Barrow Zakzak \\
2 & Compatibility & Numbered Circles Test (Jumping Circles and Eye-to-leg Compatibility) \\
3 & Balance & $\begin{array}{l}\text { Moving balance test The process of moving over the marks in zigzag for a } \\
\text { distance of } 10 \mathrm{~m}\end{array}$ \\
4 & Mental perception & The scale for mental perception \\
5 & Suppression & Ball stopping test \\
6 & Handling & Short handling test for $10 \mathrm{~m}$ \\
7 & Rolling & wave running test with the ball between $(10)$ signs \\
\hline
\end{tabular}

\section{The exploratory experience}

The researchers conducted the exploratory experiment on Sunday 1/2/2019 at (2) o'clock the afternoon for a sample consisting of (5) young players from Al-Ettifaq Club and outside the research sample in the AlDaghara Club Stadium in order to ensure the validity of the place, tools, and equipment used in the research, as well as time and validity of the tests, used.

\section{The scientific principles of the tests}

Test validation

The validity of the test is of great importance, as mentioned, which is "the accuracy which the test measures the purpose for which this test is designed" (Mukhtar, 1993). In order to extract the validity of the candidate tests that the researchers worked on, he presented them to the experts, as the researchers obtained the validity of the content.

Table 4. Shows the stability factor and the objectivity factor of the studied tests.

\begin{tabular}{llcc}
\hline $\mathrm{N}$ & The tests & Persistence & Objectivity \\
\hline 1 & Running test by Barrow Zakzak & 0.85 & 0.91 \\
2 & Numbered Circles Test (Jumping Circles and Eye-to-leg Compatibility) & 0.87 & 0.88 \\
3 & Moving balance test The process of moving over the marks in zigzag for & 0.890 & 0.92 \\
& a distance of $10 \mathrm{~m}$ & 0.84 & 0.87 \\
4 & The scale for mental perception & 0.91 & 0.90 \\
5 & Ball stopping test & 0.87 & 0.89 \\
6 & Short handling test for $10 \mathrm{~m}$ & 0.88 & 0.88 \\
7 & wave running test with the ball between (10) signs & & \\
\hline
\end{tabular}

\section{Test Stability}

In order to know the coefficient of stability for tests, the principle of the static test must be applied to the used tests, "which gives similar results or the same results if applied more than once in similar conditions" (Mukhtar, 1993). The researchers used the stability factor (test and re-test method) with a separated period between the first test and the second test (7) days for the same experimental sample. The researchers extracted the coefficient of stability by using the simple correlation coefficient (Pearson) between the first and second tests 
and extracted the significance value of the correlation by using the statistical method for the significance of the correlation as shown in Table (2-3).

Objectivity

Objectivity is defined as "the arbitrator extent of the arbitrator or examiner is liberated from personal factors" (Hara, 1990). The researchers used the simple correlation coefficient (Pearson) in order to know the objectivity of the tests between the first and second judgments, as shown in Table (2-3).

\section{Pre-tests}

The researchers conducted the pre-tests on the research sample after completing the scientific basis for the tests for the research sample on Tuesday 6/2/2019 at (2) o'clock the afternoon. In the stadium of the Daghara Sports Club, the researchers emphasized the attempt to establish all the special conditions for the tests, such as time and place, as much as required possible, in order to achieve the uniform conditions when trying to re-conduct the post-tests for the research sample, as shown in Table (2-2).

\section{Suggested training curriculums}

The researchers worked on a training curriculum from Sunday 10/2/2019, and the researchers define the training curriculum during periods of the general preparation and special preparation for the sample. The training curriculum aims to develop the most important motor abilities, basic skills, and mental perception of the sample to develop it. The researchers depended on personal experiences due to the work in the field of football training. Furthermore, they have also analysed and reviewed large numbers of studies and scientific research on football. The researchers cure the process of building the training curriculum all the scientific foundations and special principles for the success of the research.

It is no secret that the researchers present the training curriculum to a group of specialists and experts in the field of study in the science of sports training and specialists in football training. As well as the researchers give great attention to consideration of the age of the sample as well as its capabilities and capabilities. The training curriculum is considered comprehensive for the two periods of general preparation and special preparation, and the application period was (12 weeks). Training scientists agree on the effects the training curriculum on the player (agreement general of the scientist the period of the effective preparation was three months) (Farhat, 2001).

The general preparation period was (8) weeks from $10 / 2$ to $4 / 6$, and the special preparation period was (4) weeks from $7 / 4$ to $4 / 5$, and the researcher worked at a rate of (Hara, 1990) training units per week at a rate of (36) A training unit for the whole curriculum. The researcher depended on the theory of fluctuation in the training process in order to distribute the training loads.

The ratio of the training load cycle was (1-3), as this method is considered one of the best ways to obtain adaptations and raise the level of the athlete's physical, skill, and mental. This method depends on the loads not remaining at the same pace as it increases and decreases. The researchers used the training method (high-intensity interval method of the circular organization) with the use of passive rest between repetitions and stations. We must mention that the experimental sample used the training curriculum prepared by the researchers. The control group used the training curriculum that prepared by the team trainer.

\section{Post-tests}

The researchers conducted the post-tests of the sample after completing the training curriculum in the Dagara Sports Club stadium, as the tests were done on Monday 6/5/2019 and (4) pm. The researcher has tried to 
establish the conditions of the tests for the time and space aspect as much as possible in order to obtain a circumstance similar to the pre-test.

The static tests

The researchers used (SPSS) packed software for analysing of the statistical data.

\section{RESULTS}

Presentation and analysis of test results for the most important motor abilities, basic skills, and mental perception of the control group

Table 5. Showed the arithmetic mean, standard deviations, and ( $\mathrm{t}$ ) test for the pre and post-tests of the control group.

\begin{tabular}{|c|c|c|c|c|c|c|c|c|}
\hline \multirow[b]{2}{*}{$\begin{array}{l}\text { Significant } \\
\text { level }\end{array}$} & \multirow{2}{*}{$\begin{array}{l}\mathrm{T} \\
\text { value } \\
\text { in } \\
\text { table }\end{array}$} & \multirow[b]{2}{*}{$\begin{array}{l}\text { T value } \\
\text { Calculated }\end{array}$} & \multicolumn{2}{|c|}{ Post tests } & \multicolumn{2}{|c|}{ Pre tests } & \multirow[b]{2}{*}{$\begin{array}{l}\text { The } \\
\text { parameters }\end{array}$} & \\
\hline & & & $\begin{array}{l}\text { Standard } \\
\text { deviation }\end{array}$ & $\begin{array}{c}\text { Arithmetic } \\
\text { mean }\end{array}$ & $\begin{array}{l}\text { Standard } \\
\text { deviation }\end{array}$ & $\begin{array}{c}\text { Arithmetic } \\
\text { mean }\end{array}$ & & \\
\hline Significance & & 3.24 & 1.38 & 9.48 & 1.39 & 10,18 & The fitness & 1 \\
\hline Significance & & 2.89 & 1.22 & 8.91 & 1.12 & 10.01 & Compatibility & 2 \\
\hline Significance & & 3.82 & 2.01 & 7.84 & 0.57 & 5.79 & Balance & 3 \\
\hline Significance & 2.262 & 4.27 & 2.65 & 58.88 & 1.88 & 55.48 & $\begin{array}{l}\text { Mental } \\
\text { nercention }\end{array}$ & 4 \\
\hline Significance & & 3.88 & 1.54 & 5.99 & 1.36 & 2.81 & Suppression & 5 \\
\hline Significance & & 3.55 & 2.11 & 5.21 & 0.74 & 3.33 & Handling & 6 \\
\hline Significance & & 4.27 & 1.89 & 5.99 & 088 & 3.09 & Rolling & 7 \\
\hline
\end{tabular}

Note: At the degree of freedom (9), a significant level (.05).

After reviewing the results in Table (1-3) for the data of arithmetic mean and standard deviations, and the (t) test for the pre and post-tests of the control group, as it has significant differences between the pre and posttests, and it was higher than the tabular value of (T) of (2.262) at significance (.05) and this indicates that there is a significant difference between the two tests and for the post-test.

Presenting tests results for the most important motor abilities, basic skills, and mental perception of the experimental group with its analysis

Table 6. Shows the arithmetic means, standard deviations, and ( $\mathrm{t}$ ) value for the pre-test and post-tests of the experimental group.

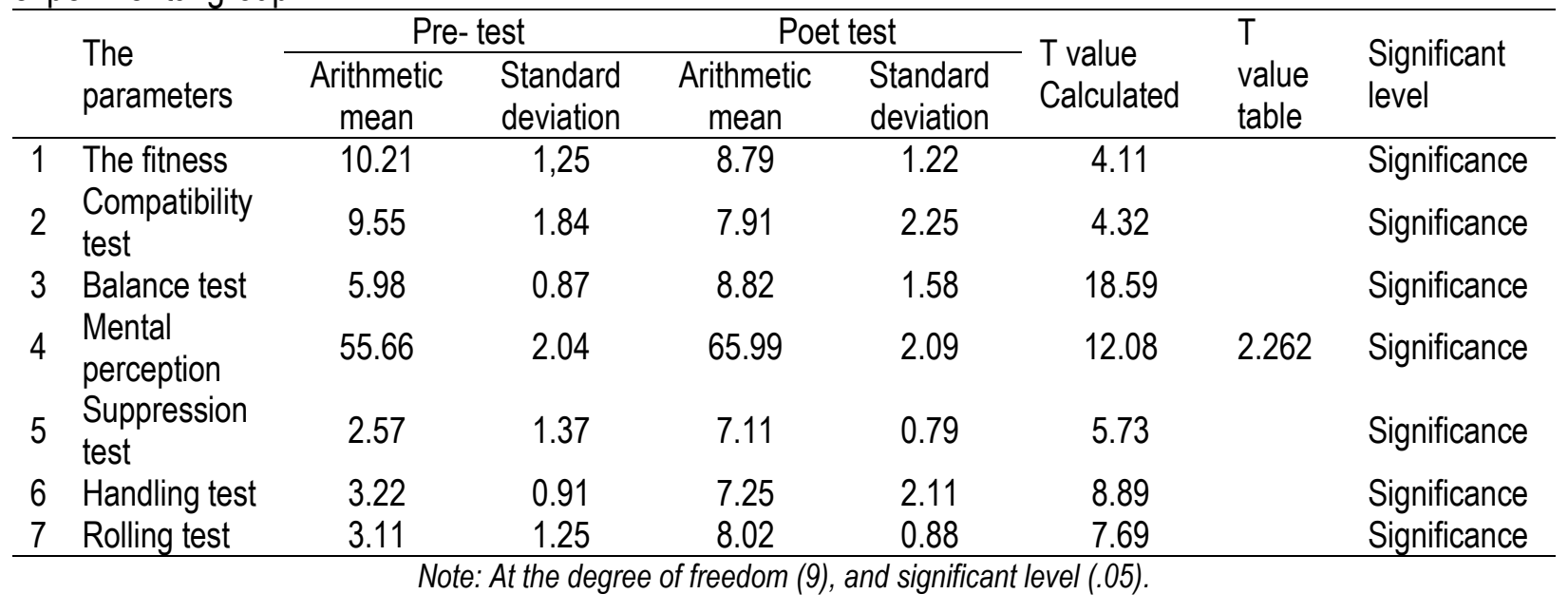


After reviewing the results in Table (2-3) for the data of arithmetic mean and standard deviations, and the (t) test for the pre and post-tests of the experimental group, there are significant differences between the pre and post-tests, and it was higher than the tabular value of (T) of (2.262) at significance (.05) and this indicates that there is a significant difference between the two tests for the post-test.

Presentation and analysis of test results for the most important motor abilities, basic skills, and mental perception of the control and experimental groups

Table 7. Shows the arithmetic means, standard deviations, and ( $t$ ) value for the pre-test and post-tests of the experimental group and control group.

\begin{tabular}{|c|c|c|c|c|c|c|c|c|}
\hline \multirow{2}{*}{\multicolumn{2}{|c|}{$\begin{array}{l}\text { The } \\
\text { parameters }\end{array}$}} & \multicolumn{2}{|c|}{ Control group } & \multicolumn{2}{|c|}{ Experimental group } & \multirow[b]{2}{*}{$\begin{array}{l}\text { T value } \\
\text { Calculated }\end{array}$} & \multirow[b]{2}{*}{$\begin{array}{l}\text { Tabular } \\
\text { T value }\end{array}$} & \multirow[b]{2}{*}{$\begin{array}{l}\text { Significant } \\
\text { level }\end{array}$} \\
\hline & & $\begin{array}{c}\text { Arithmetic } \\
\text { mean }\end{array}$ & $\begin{array}{l}\text { standard } \\
\text { deviation }\end{array}$ & $\begin{array}{c}\text { Arithmetic } \\
\text { mean }\end{array}$ & $\begin{array}{l}\text { standard } \\
\text { deviation }\end{array}$ & & & \\
\hline 1 & The fitness & 9.48 & 1.38 & 8.79 & 1.22 & 2.98 & & Significance \\
\hline 2 & $\begin{array}{l}\text { Compatibility } \\
\text { test }\end{array}$ & 8.91 & 1.22 & 7.91 & 2.25 & 9.27 & & Significance \\
\hline 3 & Balance test & 7.84 & 2.01 & 8.82 & 1.58 & 5.44 & & Significance \\
\hline 4 & $\begin{array}{l}\text { Mental } \\
\text { perception }\end{array}$ & 58.88 & 2.65 & 65.99 & 2.09 & 5.92 & 2.010 & Significance \\
\hline 5 & $\begin{array}{l}\text { Suppression } \\
\text { test }\end{array}$ & 5.99 & 1.54 & 7.11 & 0.79 & 15.38 & & Significance \\
\hline 6 & $\begin{array}{l}\text { Handling } \\
\text { test }\end{array}$ & 5.21 & 2.11 & 7.25 & 2.11 & 11.11 & & Significance \\
\hline 7 & Rolling test & 5.99 & 1.89 & 8.02 & 0.88 & 10.35 & & Significance \\
\hline
\end{tabular}

By looking at the results in Table (3-3) for the values of the arithmetic mean and standard deviations for the post-tests and the control and experimental groups, as it was found that there are differences between the two tests according to the calculated (T) values, which is greater than the tabular value of $(T)(2.010)$ at the level of significance (.05) and critical degree (18), which indicates the existence of a significant difference between the two tests in favour of the experimental group.

\section{DISCUSSION}

After presenting the results in the aforementioned tables, we find that there is an evolution of the control and experimental group, and the researchers attribute the reasons to the development of the control group in motor abilities and mental perception due to the effect of the curriculum prepared by the trainer as well as to the continuation and commitment of the players in the training process that had the role The prominent figure in the development of the mobility abilities of the players. As (Muhammad Labib and Muhammad Munir) confirm, "The natural phenomena of the learning process is that there must be an evolution in learning as long as the teacher follows the peaceful steps and foundations of the learning process and exercises the correct performance and focus on it until the performance is established and stable" (Munir, 1997).

The results also showed that there are significant differences and preferences for the experimental group in the development of some motor abilities. The researchers attribute the cause of the development to the effect of the used special exercises that prepared by the researchers, as these exercises contributed to the development of some motor abilities in the research sample, as the special exercises were performed in a regular at the intense method and for enough rest time. It was characterized by diversification and excitement 
and gives its requirements to the nature of the movement capabilities in the match. (Qasim Hasan) confirmed, "Special exercises contain an element or several elements of activity similar to the movement with direction and potential (Alian, 2005).

Also, special exercises contribute greatly to the development of some basic elements, the most important is the development of motor abilities and also be appropriate for the skilful performance of the players due to being close to or similar to the movement path. Hara mentioned "Special exercises serve to guide the integration of the fitness level of a specific element, as well as the ability to match and a technical or tactical element and link it with quality building and the psychological characterizations of competition" (AlMandalawi, 1989) All this indicates its importance for its development.

Through what was found from the presentation and analysis of the previous tables, there is a remarkable development in some basic skills of the control group, the researchers attribute the reason for this development to the effect of the regular trainers approach that put in addition to the continuity and regularity of the players in adhering to the training units and the repetition of basic skills which has a clear role in this development. (Hanafi Mahmoud) confirmed "Continuity plays an important role in reaching the player to the high level in terms of technical performance of the skill in terms of accuracy, integrity, fixation, and mechanism of high technical performance" (Hussein. 1998).

We see a preference for the experimental group in the development of some basic skills. The researchers attribute the reason for the development of motor abilities, which was the reason for the development of basic skills in the research sample. (Qasim Lazam) mentioned "Those who have a level of motor abilities will help develop basic skills" (Lazam, 2005).

The importance of motor abilities as well as training of many motor skills by using various training methods raises the level of abilities of the player (Amir, 2007). For reaching a high level of performance, the player must have high mobility abilities in order to achieve all the requirements of the game, especially during the match that takes long periods. It is mentioned "high mobility abilities increase the player's skill and planning abilities and in the right direction" (Abbas, 2003).

As we can see that the development of the research sample in terms of skill performance, which depends on several principles that are affected and effected on sports achievement. These principles are the motor abilities have the primary role in activating the will factor of the players. The movement abilities are one of the main pillars on which the physical preparation, skills, and level of achievement depend within the various sports activities (Kamsh, 2002). The high level of the mobility abilities of the players has a positive effect on their psychological and moral and increases and develops their will factor in a way that makes them able to move in an excellent manner inside the stadium.

\section{CONCLUSIONS AND RECOMMENDATIONS}

After reviewing the results, the researchers found the most important conclusions:

1. There is a clear effect of the training regime prepared by the trainer in developing motor abilities, mental perception, and basic skills of the control research sample.

2. Special exercises have a clear effect on the experimental group in developing motor abilities and mental perception.

3. The development of the motor abilities of the experimental group is better than the basic skills of the experimental research sample as a result of working with the method prepared by the researchers. 


\section{Recommendations}

After reviewing the conclusions, the researchers recommend:

1. The active trainers who work in the field of training should pay attention to developing the movement capabilities and mental perception of the young football players.

2. Emphasis on the use of special exercises for the development of motor abilities and mental perception among young football players.

\section{REFERENCES}

Hanafi Mahmoud Mukhtar: (1993). The Scientific principals in Football Training, Arab thought House, Cairo.

Hanafi Mahmoud. (1994). Football trainer. Edition 1. Cairo: Arab Thought House.

Hara. Athletic Training Origins. (1990). Translation (Abd Ali Nassif). Edition 2. Mosul: Higher Education Press.

Laila El-Sayed Farhat. (2001). Measurement and testing in physical education. Edition 1. Cairo: Book Center for Publishing.

Muhammad Labib and Muhammad Munir. (1997). Curricula and Teaching means: The Egyptian Anglo Library, Cairo.

Nader Fahmy Al-Zyoud and Hisham Amer Alian. (2005). Principles of measurement and evaluation in education. Edition 3. Amman: Thought House for Publishing and Distribution.

Qasim Al-Mandalawi et, al. (1989). The tests, the measurement and the evaluation in physical education, Mosul, Higher Education Press.

Qasim Hassan Hussein. (1998). The principals of the sports training. Edition 1. Amman: Arab Thought House for Publishing and Distribution.

Qasim Lazam. (2005). Topics in motor learning. Iraq: Higher Education Press.

Raed Abdul Amir. (2007). The percentage of the contribution of anthropometric and kinetic abilities to select gymnastic buds at (4-5) years old. Babylon University - College of Physical Education.

Warda Ali Abbas. (2003). The predictive top of the motor ability in terms of some physical measurements of the junior tennis player. College of Physical Education for Women - University of Baghdad.

Yusef Lazem Kamsh. (2002). Fitness for football players. Amman: Thought House for Printing, Publishing and Distribution.

\section{@() $\Theta \Theta \Theta$}

This work is licensed under a Attribution-NonCommercial-NoDerivatives 4.0 International (CC BY-NC-ND 4.0). 